\title{
Nitrogen budget in recirculating aquaponic systems with different fish stocking density
}

\author{
Carmelo Maucieri, Carlo Nicoletto, Giampaolo Zanin, Marco Birolo, Gerolamo Xiccato, \\ Paolo Sambo, Maurizio Borin
}

Department of Agronomy, Food, Natural resources, Animals and Environment (DAFNAE), University of Padova, Legnaro (PD), Italy

\begin{abstract}
As in any agroecosystem, also in aquaponics the nitrogen $(\mathrm{N})$ balance represents an important tool to evaluate sustainability, and to identify factors that can improve $\mathrm{N}$ use efficiency (NUE) and reduce $\mathrm{N}$ losses. In this respect, fish stocking density has been little investigated, hence this research aimed to evaluate the $\mathrm{N}$ balance of a low technology aquaponic (AP) system managed at two fish densities in comparison with a hydroponic system (HP). In the fish tanks common carp at two initial stocking densities were reared $\left(2.5\right.$ and $4.6 \mathrm{~kg} \mathrm{~m}^{-3}$ in low and high AP, hereafter named APL and APH, respectively) and the vegetated sector was cultivated with a leafy vegetable crop succession (Catalogna chicory, lettuce, Swiss chard). The $\mathrm{N}$ balance considered $\mathrm{N}$ input as fish feed or fertiliser, and $\mathrm{N}$ content in the initial water and the $\mathrm{N}$ output as $\mathrm{N}$ in the incremented fish biomass, in the harvested vegetables, in the sediments, and in the remaining water. Total $\mathrm{N}$ loss was estimated by difference. The total $\mathrm{N}$ input and the $\mathrm{N}$ loss through gas emission in the atmosphere were much higher in AP than in HP, particularly at high stocking density. The opposite trend was observed for the $\mathrm{N}$ input recovered in vegetable aboveground biomass. The $\mathrm{N}$ input recovered as fish biomass was slightly higher in APL compared to APH. The better results of APL than APH
\end{abstract}

Correspondence: Giampaolo Zanin, Department of Agronomy, Food, Natural resources, Animals and Environment (DAFNAE), University of Padova, viale dell'Università 16, I-35020 Legnaro (PD), Italy.

E-mail: paolo.zanin@unipd.it

Key words: Nitrogen budgets; aquaponics; hydroponics; stocking density; Cyprinus carpio; Cichorium intybus; Lactuca sativa; Beta vulgaris.

Acknowledgements: Project Acquaponica: nuovi sistemi integrati per un'agricoltura sostenibile - 2017 - prot. BIRD 179231; CUP: C52F17000140005) - University of Padova - Department of Agronomy, Food, Natural resources, Animals and Environment (DAFNAE).

Received for publication: 11 April 2020.

Revision received: 1 July 2020.

Accepted for publication: 2 July 2020.

(C) Copyright: the Author(s), 2020

Licensee PAGEPress, Italy

Italian Journal of Agronomy 2020; 15:1639

doi:10.4081/ija.2020.1639

This article is distributed under the terms of the Creative Commons Attribution Noncommercial License (by-nc 4.0) which permits any noncommercial use, distribution, and reproduction in any medium, provided the original author(s) and source are credited. suggest that in low-tech AP system lower initial fish density should be adopted at the system start up to maximise both production and $\mathrm{N}$ recovery.

\section{Introduction}

Aquaponics (AP), the combination of hydroponics and recirculating aquaculture, is a promising atypical and complex food production technology (Somerville et al., 2014; König et al., 2016; Maucieri et al., 2018; Goddek et al., 2019). This integrated production system is meant to increase the sustainability of both fish and vegetable production. Indeed, as summarised by Yogev et al. (2016), the main advantages of AP are related to high water use efficiency, as the volume of water used to produce both fish and vegetables is lower compared to conventional agriculture; low fertiliser use, as vegetable nutrition, is mostly fulfilled by fish feed; use of organic practices, as chemicals are frequently toxic for the fish; low land use, as no fertile soil is required for vegetable production; high smallholder welfare, as it is able to give high vitamin and protein production per unit surface area. As in typical agroecosystems, also in AP nitrogen $(\mathrm{N})$ balance represents a key point because the vegetable $\mathrm{N}$ requirements can compensate the low fish $\mathrm{N}$ use efficiency (NUE), with positive effect on both profitability and environmental impact. Indeed, as reviewed by Crab et al. (2007), purchase of commercial feed for fish farming comprises $50 \%$ or more in the production costs, mainly due to the cost of the protein component (the major source of $\mathrm{N}$ ). In addition, in aquaculture systems, only $11 \%$ to $36 \%$ of the $\mathrm{N}$ input with feed is converted into harvestable products whereas about $75 \%$ is excreted in the water by fish (Hargreaves, 1998; Gross et al., 2000). This greatly affects environment compromising quality of discharged water and increasing $\mathrm{NH}_{3}$ volatilisation and $\mathrm{N}_{2} \mathrm{O}$ emissions in the atmosphere (Muralidha et al., 2017). In this context, AP technology can be a valuable solution to reduce the environmental impact of fish production reducing $\mathrm{N}_{2} \mathrm{O}$ emission and water use along with increasing the NUE through vegetable production (Paudel, 2020). Only few studies are available on $\mathrm{N}$ balance in AP systems to evaluate the contribution of vegetables on $\mathrm{N}$ recovery from fish effluent. Endut et al. (2014) reported a $\mathrm{N}$ recovery capability of the hydroponic section of $88 \%$ of the total ammonia $\mathrm{N}$ released in the AP system by fish. Fang et al. (2017) estimated that $24.9 \%$ of $\mathrm{N}$ input was recovered in fish biomass and a further $22.3 \%$ in the vegetable biomass, while Jaeger et al. (2019) found that only $19.3 \%$ of $\mathrm{N}$ in fish feed was recovered in common carp and lettuce biomasses. A cumulative fish-vegetable NUE of $48.9 \%$ has been reported in a small-scale AP system producing common carp and pakchoi (Brassica chinensis) with minimal NUE variation between summer (43.8\%) and autumn (44.6\%) (Zou et al., 2016a, 2016b). A plant species effect on $\mathrm{N}$ recovery efficiency in AP has been found by $\mathrm{Hu}$ et al. (2015) who obtained a NUE of $41.3 \%$ and 
$34.4 \%$ in tomato (Solanum lycopersicum) and pakchoi based AP systems, respectively. Wongkiew et al. (2017a) pointed out that NUE can be improved by reducing the feed rate, that halved $\mathrm{N}$ loss when the rate was reduced from 50 to $35 \mathrm{~g} \mathrm{~d}^{-1}$, or lowering the feed-to-plant ratio, that decreased $\mathrm{N}$ loss by about $50 \%$ when the ratio decreased by $30 \%$. Finally, Paudel (2020) compared different initial plant-fish biomass ratio, and found that increasing this ratio from 0.06 to 0.95 , NUE increased from 29.3 to $39.1 \%$. To our knowledge, no studies have compared the effect of different fish stocking density, maintaining constant biofilter surface and plant density, on $\mathrm{N}$ balance in aquaponics.

In view of this, the aim of this study was to evaluate the $\mathrm{N}$ balance of a recirculating AP system managed at two fish stocking densities in a vegetable succession, in comparison with a hydroponic system. Our specific objectives were: i) assess the influence of initial fish density on $\mathrm{N}$ balance and NUE; ii) evaluate the contribution of fish and plants on $\mathrm{N}$ recovery; iii) estimate the $\mathrm{N}$ gaseous losses in the different conditions.

\section{Materials and methods}

\section{Experiment set-up}

The pilot-scale experiment has been carried out in a PE film single-span greenhouse covered with a $50 \%$ shade net, located at the experimental farm of Padova University, North-East Italy $\left(45^{\circ} 20^{\prime} \mathrm{N}\right.$; $11^{\circ} 57^{\prime} \mathrm{E} ; 6 \mathrm{~m}$ a.s.1.). The experimental treatments were: aquaponics with low fish density (APL), aquaponics with high fish density (APH) and hydroponics with no fish (HP), as control. The experiment was arranged as in a randomised block design with three replications for a total of 9 independent units.

Each experimental unit (Figure 1) consisted of: A) a tank (500 L) where in the AP units fish was farmed, whereas in the HP units only nutrient solution was present; B) two tanks, filled with $225 \mathrm{~L}$ of expanded clay as growing media (LECA Laterlite, Solignano, Italy), that received the same water flux from tank A and acted both as biofilter and cultivation tank for vegetables; C) a water storage tank (50 L volume) where the output from vegetable tanks was collected before relaunching in the tank A. In total, a surface of 0.63 $\mathrm{m}^{2}$ of tank A was combined with $1.57 \mathrm{~m}^{2}$ of vegetable production. The three parts of the system had water surfaces at different heights so that the water flow inside was guaranteed by overflow. The water accumulated in the storage tank was relaunched to the fish tank by a pump (Newa Jet 1700, NEWA Tecno Industria Srl, Loreggia, Italy) with water flow rate of $120 \mathrm{~L} \mathrm{~h}^{-1}$ allowing a complete water system recirculation every $5 \mathrm{~h}$. The water oxygenation in the tanks A was guaranteed by porous stones connected to an aerator with flow rate of $102 \mathrm{~L} \mathrm{~min}^{-1}$ (Scubla D100, Scubla Srl, Remanzacco, Italy).

The experiment started on $19^{\text {th }}$ June 2017 , when tanks were filled with a total of $600 \mathrm{~L}$ tap water, and ended on $7^{\text {th }}$ November 2017 with the harvest of fish and vegetables. On $27^{\text {th }}$ June, after water reached constant temperate, fish were put in APL and APH treatments (which through their wastes acted as $\mathrm{N}$ fertilisation), whereas in HP treatment $607 \mathrm{~g}$ per unit of $\mathrm{Ca}\left(\mathrm{NO}_{3}\right)_{2} \cdot 4 \mathrm{H}_{2} \mathrm{O}(1011$ $\mathrm{mg} \mathrm{L}^{-1}$ ) were added. Except $\mathrm{N}$, all 9 units contained the same nutrient solution $\left(220 \mathrm{mg} \mathrm{L}^{-1}\right.$ of $\mathrm{KH}_{2} \mathrm{PO}_{4}, 330 \mathrm{mg} \mathrm{L}^{-1}$ of $\mathrm{K}_{2} \mathrm{SO}_{4}$, $456 \mathrm{mg} \mathrm{L}^{-1}$ of $\mathrm{MgSO}_{4} \cdot 7 \mathrm{H}_{2} \mathrm{O}, 31 \mathrm{mg} \mathrm{L}^{-1}$ of Fe-EDTA, and $13 \mathrm{mg}$ $\mathrm{L}^{-1}$ of micronutrients). In the AP units, tanks A were stocked with full-scaled common carp (Cyprinus carpio L.) obtained from a commercial farm with an initial live weight of $169 \pm 56 \mathrm{~g}$ at initial stocking densities of $2.5 \mathrm{~kg} \mathrm{~m}^{-3}$ and $4.6 \mathrm{~kg} \mathrm{~m}^{-3}$ for APL and APH treatments (i.e. 7 and 14 fishes per unit), respectively. The follow- ing crops succession was cultivated in the vegetable tanks: Catalogna chicory (Cichorium intybus L. Catalogna group - from June $27^{\text {th }}$ to July $25^{\text {th }}, 9$ plants $\mathrm{m}^{-2}$ ), lettuce (Lactuca sativa L. from July $26^{\text {th }}$ to August $29^{\text {th }}, 12$ plants $\mathrm{m}^{-2}$ ) and Swiss chard (Beta vulgaris L. subsp. vulgaris, Cicla Group - from August $29^{\text {th }}$ to November $7^{\text {th }}, 10$ plants $\mathrm{m}^{-2}$ ).

\section{Operation and monitoring of the system}

Fish health status and mortality were monitored daily. The fish were manually fed once a day with a commercial extruded sinking pelleted feed (Classic K, Skretting, Verona, Italy; $41.1 \%$ crude protein). In the units, water was never changed throughout the trial. Water lost by evapotranspiration of each unit was manually refilled daily.

\section{Sampling and analytical methods}

Two times per week water was monitored for: i) in situ temperature, dissolved oxygen (DO), $\mathrm{pH}$, redox potential (ORP), and electrical conductivity (EC) using a portable multi-parameter meter (HQ40d Portable Multi-Parameter Meter, Hach Lange $\mathrm{GmbH}$, Germany); ii) in laboratory, water $\mathrm{NO}_{2}^{-}, \mathrm{NO}_{3}^{-}$, and $\mathrm{NH}_{4}{ }^{+}$ concentration were determined by ion chromatography (ICS-900 system, Dionex Corp., Milan, Italy). Six times during the experimental period, the water used to refill evapotranspiration losses was analysed for $\mathrm{NO}_{2}{ }^{-}, \mathrm{NO}_{3}{ }^{-}$, and $\mathrm{NH}_{4}{ }^{+}$concentrations. In the result section, data are expressed as $\mathrm{NO}_{2}-\mathrm{N}, \mathrm{NO}_{3}-\mathrm{N}$, and $\mathrm{NH}_{4}-\mathrm{N}$. All fishes from each unit were weighed individually every month (five times) during the experimental period and the feed quantity to be administered daily was calculated for each AP unit on the base of biomass present at the moment of each weighing at rate ranging from $0.5 \%$ to $2 \%$ (Maucieri et al., 2019). Total feed $\mathrm{N}$ content was determined by Kjeldahl method. Total $\mathrm{N}$ content of carp biomass $(2.7 \%)$ was estimated considering an average of literature data (Schwarz et al., 1998; Skibniewska et al., 2013).

At harvest time plants were gathered, divided into above and belowground biomass, and dried in a thermo-ventilated oven at $65^{\circ} \mathrm{C}$ until a constant weight was reached to determine dry weight and dry matter content. Total $\mathrm{N}$ content in the biomass was determined by Kjeldahl method.

At the end of the experiment the expanded clay content in the vegetable tanks was removed and washed with fresh water to collect tanks sediment. The sediment was dried in a thermo-ventilated oven at $65^{\circ} \mathrm{C}$ until a constant weight was reached. After that, total $\mathrm{N}$ content in the dry sediment was determined by CNS Macrovario combustion analyser (Elementar Analysensysteme $\mathrm{GmbH}$, Germany) and values have been expressed as percentage on dry matter.

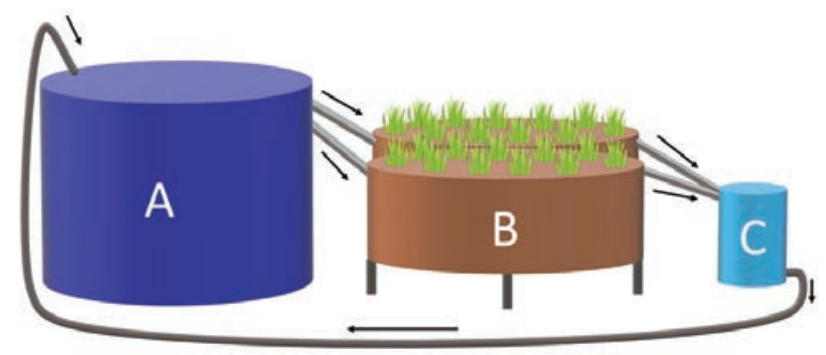

Figure 1. Experimental unit layout. A: tank for fish in aquaponic treatments or nutrient solution for hydroponic treatments $(500$ L); B: tank for vegetables/biofilter (275 L); C: storage tank for water $(50 \mathrm{~L})$. Arrows indicate water flow direction. 


\section{Estimation of nitrogen species and mass balance}

The $\mathrm{N}$ mass balance was calculated considering the different $\mathrm{N}$ species measured in the experiment. In particular, $\mathrm{N}$ input was originated by the application of feed (in APL and APH), fertiliser (HP) and by the $\mathrm{N}$ water content (in initial and additional water). The measured $\mathrm{N}$ species were the total $\mathrm{N}$ contained in the fish, in the vegetables, in the sediments and in the residual water at the end of experiment. The difference between total input and output was accounted to gaseous losses. Hence, $\mathrm{N}$ balance was calculated according to the following equation:

$\mathrm{N}_{\text {feedffertiliser }}$ in $+\mathrm{N}_{\text {water }}$ in $=\mathrm{N}_{\text {fish }}$ out $+\mathrm{N}_{\text {plants }}$ out $+\mathrm{N}_{\text {sediment }}$ out $+\mathrm{N}_{\text {water }}$ out $+\mathrm{N}_{\text {gas }}$ out

Where:

$\mathrm{N}_{\text {feed/fertiliser }}$ in $(\mathrm{g})=$ Feed supplied $(\mathrm{g}) \times$ Total Kjeldahl Nitrogen $(\mathrm{TKN})(\%)$ or Fertiliser supplied $(\mathrm{g}) \times \mathrm{N}(\%)$

$\mathrm{N}_{\text {water }}$ in $(\mathrm{g})=$ (Initial water volume + Evapotranspiration refill) (L) $\times\left(\mathrm{NO}_{3}-\mathrm{N}+\mathrm{NO}_{2}-\mathrm{N}+\mathrm{NH}_{4}-\mathrm{N}\right)\left(\mathrm{g} \mathrm{L}^{-1}\right)$

$\mathrm{N}_{\text {fish }}$ out $(\mathrm{g})=($ final fish weight - initial fish weight $)(\mathrm{g}) \times 2.7 \%$

$\mathrm{N}_{\text {plants }}$ out $(\mathrm{g})=$ Vegetables biomass $(\mathrm{g}) \times \mathrm{TKN}(\%)$

$\mathrm{N}_{\text {sediment }}$ out $(\mathrm{g})=$ Sediment dry weight $(\mathrm{g}) \times \mathrm{N}(\%)$

$\mathrm{N}_{\text {water }}$ out $(\mathrm{g})=$ Final water volume $(\mathrm{L}) \times\left(\mathrm{NO}_{3}-\mathrm{N}+\mathrm{NO}_{2}-\mathrm{N}+\mathrm{NH}_{4}-\right.$ N) $\left(\mathrm{g} \mathrm{L}^{-1}\right)$

$\mathrm{N}_{\text {gas }}$ out $(\mathrm{g})=$ the amount of $\mathrm{N}$ that was not recovered through water, sediments, plants and fish and represents the $\mathrm{N}$ lost through ammonia volatilisation and nitrification/denitrification (Wongkiew et al., 2017b). As this is the only unknown variable, it was calculated by difference.

Water dissolved organic $\mathrm{N}$ content was not considered in our budget for two reasons: i) it was absent in the water used to fill and refill systems as municipal drinking water was used; ii) it can be considered negligible in the residual water (Hargreaves, 1998). Fish solid wastes and uneaten feed, suspended in water, were trapped in the biofilter and their total $\mathrm{N}$ content was considered in the budget as $\mathrm{N}$-sediment out whereas the residual dissolved organic $\mathrm{N}$ in the water was mineralised by proteolytic and heterotrophic bacteria to dissolved inorganic substances (especially ammonia) (Hargreaves, 1998).

\section{Statistical analysis}

Data were checked for homogeneity of variance across treatments by using Kolmogorov-Smirnov test. Normal distributed data (systems ET and N budget components) were analysed using analysis of variance (ANOVA) and when significant $(\mathrm{P}<0.05)$, means were separated by Tukey's HSD test.

For data not normally distributed (water temperature, dissolved oxygen, electrical conductivity and $\mathrm{pH}$ ), Kruskal-Wallis nonparametric test (accepted at the level of $\mathrm{P}<0.05$ ) was used to check the significance of differences.

\section{Results and discussion}

\section{Water management}

Daily water consumption in the experimental units due to evapotranspiration was not significantly different among treatments with an average value of $3.7 \mathrm{~L} \mathrm{~m}^{-2}$ day ${ }^{-1}$, equal to a daily evapotranspiration of $1.37 \%$ compared to the total water content of the system. A significant seasonal effect was found according to the crop cycle with the highest average consumptions monitored during summer cycles (Catalogna $5.1 \mathrm{~L} \mathrm{~m}^{-2}$ day $^{-1}$ and lettuce 5.3 $\mathrm{L} \mathrm{m}^{-2}$ day $^{-1}$ ) and the lowest during summer-autumn Swiss chard cycles (2.1 L m$~^{-2}$ day $^{-1}$ ) (Figure 2). The lower water consumption during Swiss chard cycle is likely due to the low temperature that both reduced evapotranspiration and plant growth rate (Maucieri et al., 2019). Daily water evapotranspiration of our experimental AP gave typical performance of AP commercial systems (daily evapotranspiration from $0.05 \%$ to $5 \%$ of system total water content) (Maucieri et al., 2018). The cumulative AP system water consumption per cultivated unit surface was $143 \mathrm{~L} \mathrm{~m}^{-2}, 175 \mathrm{~L} \mathrm{~m}^{-2}$, and 147 $\mathrm{L} \mathrm{m}^{-2}$ for Catalogna chicory, lettuce, and Swiss chard cycles, respectively. Values are in line with water consumptions that these species have in traditional cultivation systems $\left(120-200 \mathrm{~L} \mathrm{~m}^{-2}\right.$, 150-200 L m$~^{-2}$, and 150-250 $\mathrm{L} \mathrm{m}^{-2}$ for Catalogna chicory, lettuce, and Swiss chard, respectively). Considering that the AP system, in addition of vegetables also provided fish biomass, the water use efficiency was actually higher, confirming that AP is a water saving technology. At the beginning of the experiment each aquaponic unit was filled with $600 \mathrm{~L}$ of water whereas in the whole experimental period $1096 \mathrm{~L}, 1123 \mathrm{~L}$, and $1069 \mathrm{~L}$ were supplied to refill evapotranspired water in the HP, APL, and APH treatments, respectively, with an average concentration of $4.04 \mathrm{mg} \mathrm{NO}_{3}-\mathrm{N} \mathrm{L}^{-1}$ and $0.19 \mathrm{mg} \mathrm{NH}_{4}-\mathrm{N} \mathrm{L}^{-1}$. Cumulatively, $7.18 \pm 0.33 \mathrm{~g} \mathrm{~N}, 7.29 \pm 0.20$ $\mathrm{g} \mathrm{N}, 7.06 \pm 0.03 \mathrm{~g} \mathrm{~N}$ were added with water $\left(\mathrm{N}_{\text {water }}\right.$ in $)$ in $\mathrm{HP}, \mathrm{APL}$, and APH treatments, respectively.

The highest $\mathrm{NH}_{4}-\mathrm{N}$ concentration was measured at the beginning of the experiment. In about one week $\mathrm{NH}_{4}-\mathrm{N}$ concentration dramatically decreased with, in the same time, a dramatic increase of $\mathrm{NO}_{2}{ }^{-}$concentration. Unlike $\mathrm{NH}_{4}-\mathrm{N}$ and $\mathrm{NO}_{2}-\mathrm{N}, \mathrm{NO}_{3}-\mathrm{N}$ concentration followed a treatment specific trend: i) in HP treatment values decreased progressively from the beginning to the end of the experiment; ii) in the APL treatment the $\mathrm{NO}_{3}^{-}$concentration increased from the third week to the end of September, then tendentially decreased; iii) in the APH treatment the $\mathrm{NO}_{3}-\mathrm{N}$ concentration remained stable near zero for all the experimental period (Figure 3). Evolution over time of $\mathrm{N}$ forms in AP treatments showed similar trends of which observed by Hu et al. (2015) and Zou et al. (2016a). The highest $\mathrm{NH}_{4}^{+}$and $\mathrm{NO}_{2}^{-}$concentrations, observed during the first three experimental weeks, were due to the slow growth of nitrifying bacteria that determined an accumulation of intermediate $\mathrm{N}$ forms $\left(\mathrm{NH}_{4}^{+}\right.$and $\left.\mathrm{NO}_{2}^{-}\right)$( $\mathrm{Hu}$ et al., 2015). Particularly, in AP systems $\mathrm{N}$ was daily supplied in organic form (feed protein) that was metabolised by fish and released in form of ammonia. Subsequently, ammonia can be oxidized to $\mathrm{NO}_{2}^{-}$by ammonia oxidizing bacteria and then in $\mathrm{NO}_{3}{ }^{-}$by nitrite oxidizing bacteria (Wongkiew et al., 2017b). However, the growth rate of the bacteria involved in the nitrification process is unpaired determining intermediate accumulation (ammonia oxidizing bacteria have a

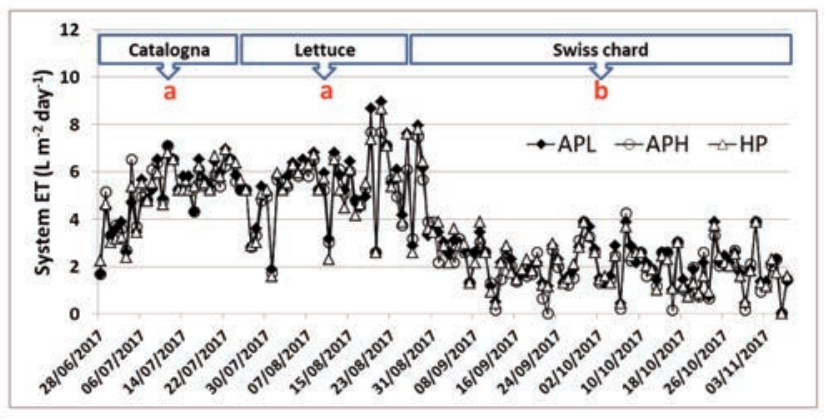

Figure 2. Daily addition of freshwater to the units to compensate evapotranspired water. Different letters indicate significant differences among average values of each growing cycle by Tukey's HSD test at $P<0.05$. HP, hydroponic unit; APL, low fish density aquaponic unit; APH, high fish density aquaponic unit. 
faster growth rate than nitrite oxidizing bacteria at temperature above $25^{\circ} \mathrm{C}$ ) (Yamamoto et al., 2008). The lack of $\mathrm{NO}_{3}{ }^{-}$concentration increase in the APH treatment during all experimental period was due to the higher fish density that determined, in the hydroponic section, a higher accumulation of organic matter and a lower oxygen content than APL. These conditions have probably determined a favourable environment for a greater denitrifying bacteria growth which determined $\mathrm{NO}_{3}{ }^{-}$reduction (Endut et al., 2010).

At the end of the experiment the $\mathrm{N}$ concentrations of residual water in the system were significantly different among treatments with the highest and lowest residual $\mathrm{N}$ found in HP and APH treatments, respectively (Table 1).

\section{Environmental conditions}

Water temperature was not different among treatments whereas significantly lower values were observed during Swiss chard cycle (summer-autumn crop) than Catalogna and lettuce cycles (summer crops) (Figure 4). Water temperature (range $14-31{ }^{\circ} \mathrm{C}$ ) was always within the indicative absolute cold and heat stress temperatures of $5^{\circ}$ and $35^{\circ} \mathrm{C}$ for common carp (Koehn, 2004), and during the majority of the experiment close to the optimum temperature (i.e. $15-31{ }^{\circ} \mathrm{C}$ ) indicated by Jaxion-Harm and Ladich (2014), and able to guarantee optimal performance at both nitrification (Kinyage and Pedersen, 2016) and denitrification (Akratos and Tsihrintzis, 2007; Xu et al., 2016) processes.

Dissolved oxygen was significantly different among treatments and crops with higher values observed in the HP treatment compared to AP treatments and in Catalogna and Swiss chard crops compared to lettuce (Figure 5). This water parameter is one of the factors that influence nitrification with a consumption approximately ranging from $4.18 \mathrm{mg}$ to $4.57 \mathrm{mg}$ of oxygen per $\mathrm{mg}$ of $\mathrm{NH}_{4}-\mathrm{N}$ oxidized to $\mathrm{NO}_{3}-\mathrm{N}$ (Chen et al., 2006; Vymazal, 2007). Thus, the lower dissolved oxygen values in the AP treatments, in addition to fish metabolism and respiration, was due to nitrification process. As far as crop effect is concerned, lettuce had much higher growth rate compared to Catalogna (Maucieri et al., 2019), hence consuming more oxygen for aerobic respiration (Ehret et al., 2010; Lara et al., 2011); then, Swiss chard had lower growth rate, but water temperature was lower, increasing oxygen solubility (TrejoTéllez and Gómez-Merino, 2012; Al-Rawahy et al., 2019).

A different trend among treatments was observed considering water EC with a constant decrease in the HP treatment, and steady pattern in the other two treatments in Catalogna chicory and lettuce crops; a decrease in values was observed in Swiss chard as well, but beginning from the second half of the cycle (Figure 6). In the HP treatment, all nutrients were added with fertiliser to the water only at the beginning of the experiment, and then nutrient concentrations decreased because of the plant up-take. Differently, in AP treatments $\mathrm{N}$ was not provided with fertiliser, and thus was lower. In the Catalogna and lettuce crop cycles EC remained constant because nutrients released through fish feces were taken up by plants at the same rate. In the last crop cycle, the initial growth rate of Swiss chard plants was very low, leading to an increase of ions

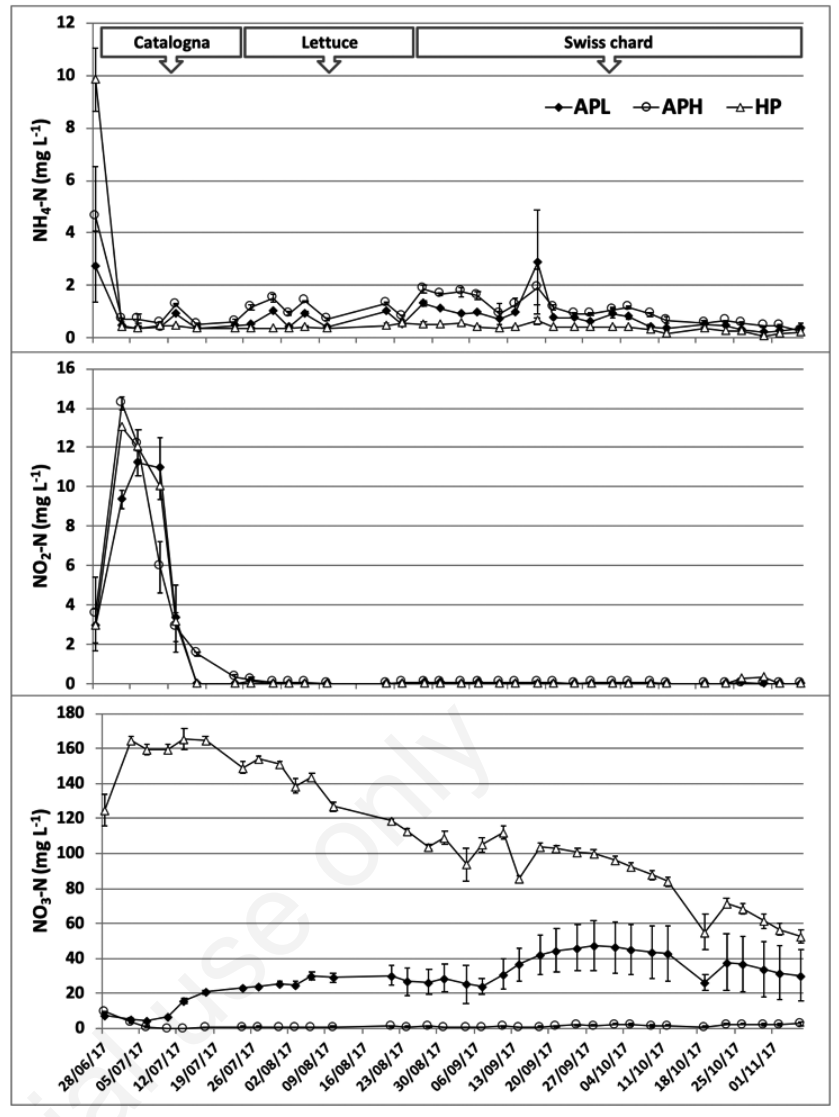

Figure 3. Daily water $\mathrm{NH}_{4}-\mathrm{N}, \mathrm{NO}_{2}-\mathrm{N}$ and $\mathrm{NO}_{3}-\mathrm{N}$ concentrations in units' water during the experimental period. HP, hydroponic unit; APL, low fish density aquaponic unit; APH, high fish density aquaponic unit.

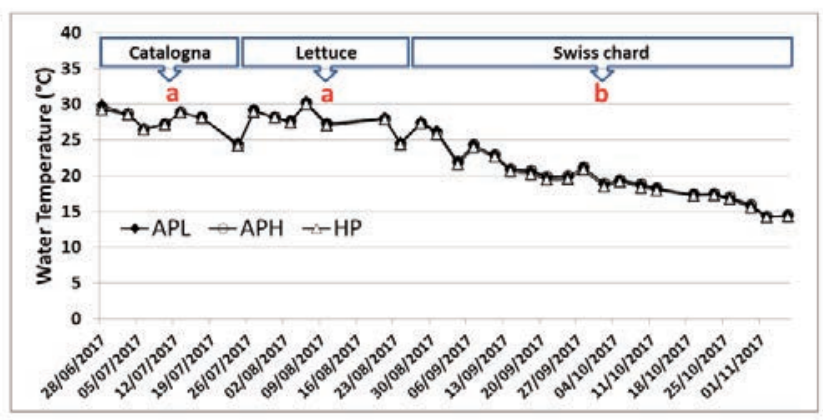

Figure 4. Water temperature $\left({ }^{\circ} \mathrm{C}\right)$ during experimental period. Different letters indicate significant differences among median values of each growing cycles by Kruskal-Wallis test at $\mathbf{P}<0.05$. HP, hydroponic unit; APL, low fish density aquaponic unit; $\mathrm{APH}$, high fish density aquaponic unit.

Table 1. Nitrogen content in the systems' residual water at the end of the experiment.

\begin{tabular}{lccccccc} 
Treatment & $\begin{array}{c}\mathrm{NO}_{2}^{-} \\
\left(\mathrm{mg} \mathrm{L}^{-1}\right)\end{array}$ & $\begin{array}{c}\mathrm{NO}_{3}^{-} \\
\left(\mathrm{mg} \mathrm{L}^{-1}\right)\end{array}$ & $\begin{array}{c}\mathrm{NH}_{4}{ }^{-} \\
\left(\mathrm{mg} \mathrm{L}^{-1}\right)\end{array}$ & $\begin{array}{c}\mathrm{NO}_{2}-\mathrm{N} \\
(\mathrm{g})\end{array}$ & $\begin{array}{c}\mathrm{NO}_{3}-\mathrm{N} \\
(\mathrm{g})\end{array}$ & $\begin{array}{c}\left.\mathrm{NH}_{4}-\mathrm{N}^{\mathrm{g}}\right) \\
(\mathrm{g})\end{array}$ & $\begin{array}{c}\mathrm{N}_{\text {water }} \\
(\mathrm{g})\end{array}$ \\
$\mathrm{HP}$ & $0.05^{\mathrm{ns}}$ & $233.58^{\mathrm{a}}$ & $0.27^{\mathrm{ns}}$ & $0.01 \pm 0.01^{\mathrm{ns}}$ & $31.65 \pm 3.80^{\mathrm{a}}$ & $0.12 \pm 0.05^{\mathrm{ns}}$ & $31.8 \pm 3.8^{\mathrm{a}}$ \\
APL & $0.04^{\mathrm{ns}}$ & $134.85^{\mathrm{ab}}$ & $0.48^{\mathrm{ns}}$ & $0.00 \pm 0.00^{\mathrm{ns}}$ & $18.27 \pm 15.42^{\mathrm{ab}}$ & $0.23 \pm 0.20^{\mathrm{ns}}$ & $18.5 \pm 15.3^{\mathrm{ab}}$ \\
\hline APH & $0.08^{\mathrm{ns}}$ & $12.10^{\mathrm{b}}$ & $0.35^{\mathrm{ns}}$ & $0.01 \pm 0.01^{\mathrm{ns}}$ & $1.64 \pm 0.82^{\mathrm{b}}$ & $0.16 \pm 0.09^{\mathrm{ns}}$ & $1.8 \pm 0.8^{\mathrm{b}}$ \\
\hline
\end{tabular}

a,bMeans in the same column followed by different letters indicate significant differences by Tukey's HSD test at P<0.05. ns, not significant differences; HP, hydroponic unit; APL, low fish density aquaponic unit; APH, high fish density aquaponic unit. 
that were not promptly taken up, but later plants nutritional needs augmented and thus EC decreased.

Water $\mathrm{pH}$ ranged between 7.0 and 9.0 without differences among treatments; higher water $\mathrm{pH}$ values were measured during the first crop cycle whereas similar values were detected during lettuce and Swiss chard cycles (Figure 7). This parameter is one of the key factors in AP systems because it influences fish, plants and microbes at the same time but optimal values are different for each of the three organisms (Tyson et al., 2011; Goddek et al., 2015). In this experiment $\mathrm{pH}$ ranged from 7.0 to 9.0 , within the tolerated $\mathrm{pH}$ for aquaponics, even if it has to be taken into account that NUE decreases as $\mathrm{pH}$ value increases (Zou et al., 2016c).

In our study, during the first crop period the average $\mathrm{pH}$ was near 8.5, values that speed up nitrifying bacteria development (Tyson et al., 2004) while reducing denitrifying bacteria activity (Zou et al., 2016c). However, in order to keep $\mathrm{pH}$ values closer to vegetables needs, in the other two cycles $\mathrm{pH}$ values were maintained (adding phosphoric acid) near to 8.0, in accordance with optimum $\mathrm{pH}$ for aquaponics as stated by Goddek et al. (2015).

\section{Fish performance}

Fish health was very good during the whole trial and only two fish died ( 1 from APL and 1 from APH treatments) and, at the end of the trial, fishes weighed $446 \pm 147 \mathrm{~g}$, on average. About feed, $3443.6 \pm 79.0 \mathrm{~g} \mathrm{system}^{-1}$ (APL) and 6387.5 $\pm 187.4 \mathrm{~g} \mathrm{system}^{-1}$ $(\mathrm{APH})$ were added during experimental period which represent the $96.9 \%$ and $98.3 \%$ of total $\mathrm{N}$ input in the APL and APH treatments, respectively. In other terms, while APL showed a significant lower $\mathrm{N}$ input with fish feed of $46.1 \%$ than $\mathrm{APH}$, the $\mathrm{N}$ output with fish biomass was only $35.4 \%$ lower in the APL than APH treatment (Table 2). In the HP treatment, where mineral $\mathrm{N}$ was added, the $\mathrm{N}$ input was $72.0 \mathrm{~g} \mathrm{system}^{-1}$ ( $\mathrm{N}_{\text {fertiliser }}$ in).

\section{Vegetables performance}

Vegetables yield was significantly different among treatments during all crop cycles (Maucieri et al., 2019; Maucieri et al., 2020). Vegetables biomass N uptake was significantly different among treatments with better performance for APL and HP treatments whereas for all cropping cycle the APH showed the worse performance (Table 3). Considering cumulative $\mathrm{N}$ uptake in the

Table 2. Nitrogen applied to the treatments through feed $\left(\mathrm{N}_{\text {feed }}\right.$ in) and outgoing as $\mathrm{N}$ in fish (difference between final and initial values) ( $\mathrm{N}_{\text {fish }}$ out $)$.

\begin{tabular}{|c|c|c|}
\hline Treatment & $\begin{array}{c}\mathbf{N}_{\text {feed }} \text { in } \\
\left(\text { g system }^{-1}\right)\end{array}$ & $\begin{array}{c}\mathrm{N}_{\text {fish }} \text { out } \\
\left(\mathrm{g}_{\text {system }} \text { sys) }\right.\end{array}$ \\
\hline APL & $226.7 \pm 5.2^{\mathrm{b}}$ & $60.0 \pm 3.2^{b}$ \\
\hline $\mathrm{APH}$ & $420.5 \pm 12.3^{a}$ & $92.9 \pm 13.3^{\mathrm{a}}$ \\
\hline
\end{tabular}

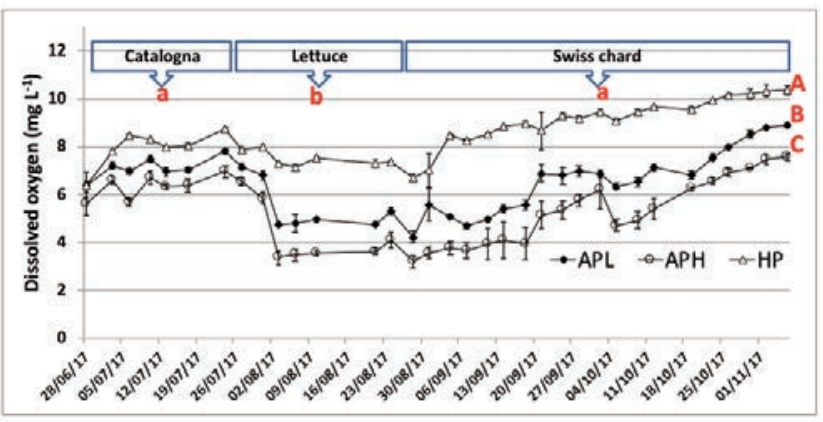

Figure 5. Dissolved oxygen in the units' water during experimental period. Different letters indicate significant differences among median values of each growing cycles (lowercase) and treatments (uppercase) by Kruskal-Wallis test at $\mathrm{P}<0.05$. HP, hydroponic unit; APL, low fish density aquaponic unit; APH, high fish density aquaponic unit.

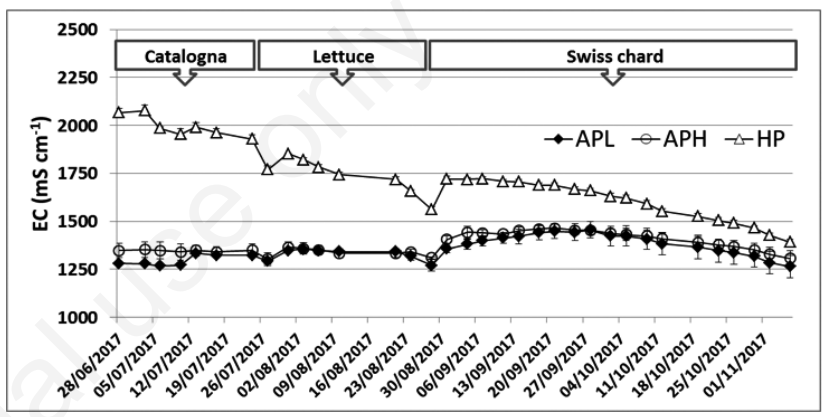

Figure 6. Water electrical conductivity (EC) during experimental period. HP, hydroponic unit; APL, low fish density aquaponic unit; $\mathrm{APH}$, high fish density aquaponic unit.

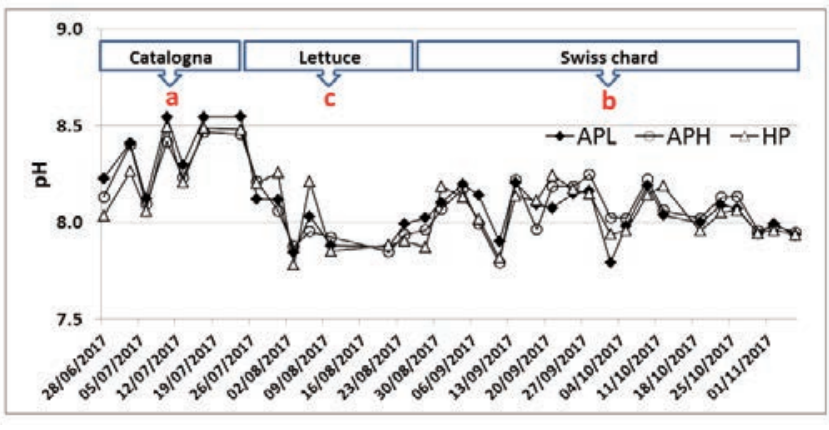

Figure 7. Water $\mathrm{pH}$ during experimental period. Different letters indicate significant differences among median values of each growing cycles by Kruskal-Wallis test at $\mathrm{P}<0.05$. HP, hydroponic unit; APL, low fish density aquaponic unit; APH, high fish density aquaponic unit.

Table 3. Vegetables biomass nitrogen concentration and uptake.

\begin{tabular}{|c|c|c|c|c|c|c|c|}
\hline \multirow[t]{2}{*}{ Treatment } & \multicolumn{3}{|c|}{ Biomass N (\%) } & \multicolumn{3}{|c|}{ Biomass $\mathbf{N}$ uptake (g) } & \multirow{2}{*}{$\begin{array}{c}\mathbf{N}_{\text {plants }} \text { out } \\
(\text { g system } \\
\text { ( }) \text { ) }\end{array}$} \\
\hline & Catalogna chicory & Lettuce & Swiss chard & Catalogna chicory & Lettuce & Swiss chard & \\
\hline HP & $3.60^{\mathrm{a}}$ & $3.84^{\mathrm{a}}$ & $2.91^{\mathrm{ns}}$ & $4.40 \pm 0.31^{\mathrm{a}}$ & $7.05 \pm 1.18^{\mathrm{a}}$ & $7.79 \pm 0.79^{b}$ & $19.2 \pm 1.5^{b}$ \\
\hline APL & $3.47^{\mathrm{a}}$ & $3.80^{\mathrm{a}}$ & $3.00^{\mathrm{ns}}$ & $3.48 \pm 0.38^{b}$ & $7.02 \pm 0.72^{\mathrm{a}}$ & $11.04 \pm 1.03^{\mathrm{a}}$ & $21.5 \pm 0.8^{a}$ \\
\hline $\mathrm{APH}$ & $2.46^{\mathrm{b}}$ & $3.20^{\mathrm{b}}$ & $2.97^{\mathrm{ns}}$ & $2.05 \pm 0.51^{\mathrm{c}}$ & $4.21 \pm 0.61^{\mathrm{b}}$ & $8.62 \pm 0.91^{\mathrm{b}}$ & $14.9 \pm 1.6^{\mathrm{c}}$ \\
\hline
\end{tabular}

a,b Means in the same column followed by different letters indicate significant differences by Tukey's HSD test at $\mathrm{P}<0.05$. ns, not significant differences; HP, hydroponic unit; APL, low fish density aquaponic unit; APH, high fish density aquaponic unit. 
three crop cycles the best performance was obtained for APL treatment with a higher uptake of $12.0 \%$ and $44.3 \%$ than HP and APH, respectively. The $\mathrm{N}$ uptake for vegetated unit surface was $13.7 \mathrm{~g} \mathrm{~N}$ $\mathrm{m}^{-2}$ and $9.5 \mathrm{~g} \mathrm{~N} \mathrm{~m}^{-2}$ equal to a daily average uptake of $97.2 \mathrm{mg} \mathrm{N}$ $\mathrm{m}^{-2} \mathrm{~d}^{-1}$ and $67.4 \mathrm{mg} \mathrm{N} \mathrm{m}^{-2} \mathrm{~d}^{-1}$ for APL and APH, respectively. Considering the daily average $\mathrm{N}_{\text {feed }}$ in $\left(1.0\right.$ and $1.9 \mathrm{~g} \mathrm{~N} \mathrm{~m}^{-2} \mathrm{~d}^{-1}$ for APL and APH, respectively), the daily vegetables uptake represents only the $9.7 \%$ and $3.5 \%$ of $\mathrm{N}$ supplied with feed in APL and APH treatments, respectively.

\section{Sediment}

Sediment production was different among treatments with the highest value in APH treatment and the lowest value in HP. This was expected, as sediments derive from deposition of fish feed and feces (Grant et al., 2019) which of course increased with increasing stoking density. No statistical differences among treatments were obtained considering sediment $\mathrm{N}$ concentration and content (Table 4).

\section{Nitrogen mass balance}

During the experimental period the total $\mathrm{N}$ input $\left(\mathrm{N}_{\text {feed/fertiliser }}\right.$ in $+\mathrm{N}_{\text {water }}$ in) was $79.2 \pm 0.3 \mathrm{~g}, 234.0 \pm 5.2 \mathrm{~g}$, and $427.6 \pm 12.4 \mathrm{~g}$ per unit for HP, APL, and APH treatments, respectively. At the end of the experimental period the $\mathrm{N}$ recovered as fish, plants, sediment and water was $91.4 \%, 53.9 \%$, and $32.3 \%$ of the total $\mathrm{N}$ input for HP, APL, and APH, respectively (Figure 8). The useful $\mathrm{N}$ recovery (plant + fish) was 16.1, 45.0 and $54.1 \mathrm{~g} \mathrm{~m}^{-2}$ for HP, APL, and APH treatments, equal to $24.2 \%, 34.8 \%$, and $25.2 \%$ of total $\mathrm{N}$ input, respectively. The fraction to reach the $100 \%\left(\mathrm{~N}_{\text {gas }}\right.$ out) was represented by $\mathrm{N}$ that was released in the atmosphere as gas compounds (e.g. $\mathrm{N}_{2}, \mathrm{~N}_{2} \mathrm{O}$ ) during $\mathrm{N}$ nitrification and denitrification and $\mathrm{N}$ released in the atmosphere as $\mathrm{NH}_{3}$ (Wongkiew et al., 2017b).

Table 4. Sediment production, nitrogen concentration and content.

\begin{tabular}{lccc} 
Treatment & $\begin{array}{c}\text { Sediment } \\
(\mathrm{g})\end{array}$ & $\begin{array}{c}\text { Sediment } \mathbf{N} \\
(\%)\end{array}$ & $\begin{array}{c}\mathbf{N}_{\text {sediment }} \text { out } \\
(\mathrm{g})\end{array}$ \\
HP & $548.6 \pm 51.7^{\mathrm{b}}$ & $0.95^{\mathrm{ns}}$ & $5.3 \pm 2.4^{\mathrm{ns}}$ \\
APL & $806.3 \pm 176.7^{\mathrm{ab}}$ & $1.09^{\mathrm{ns}}$ & $8.6 \pm 1.8^{\mathrm{ns}}$ \\
\hline APH & $1076.1 \pm 254.0^{\mathrm{a}}$ & $1.53^{\mathrm{ns}}$ & $17.3 \pm 8.5^{\mathrm{ns}}$ \\
\hline
\end{tabular}

a,bMeans in the same column followed by different letters indicate significant differences by Tukey's HSD test at $\mathrm{P}<0.05$. ns, not significant differences; HP, hydroponic unit; APL, low fish density aquaponic unit; $\mathrm{APH}$, high fish density aquaponic unit.

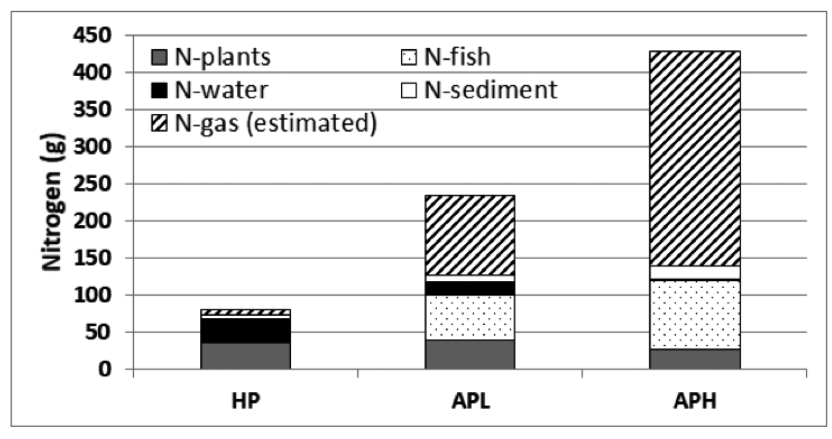

Figure 8. Experimental units' nitrogen $(\mathrm{N})$ apparent balance. $\mathrm{HP}$, hydroponic unit; APL, low fish density aquaponic unit; APH, high fish density aquaponic unit.
The N supplied with feed and recovered with fish biomass was $26.5 \%$ and $22.1 \%$ in APL and APH, respectively, in line with literature data (11\%-36\%) (Hargreaves, 1998; Gross et al., 2000; Hu et $a l ., 2015)$. These data confirm the low aquaculture NUE and highlight the great potential of AP technology in increasing of aquaculture NUE, reducing at the same time, the environmental impact related to the treatment and disposal of aquaculture wastewater.

Denitrification is an anoxic process, in which $\mathrm{NO}_{3}-$ is reduced to $\mathrm{NO}_{2}-$ and subsequently to $\mathrm{N}_{2 \text { (gas) }}$ by heterotrophic denitrifying bacteria, directly and/or indirectly affected by several factors as carbon source, nitrate loading rate, oxygen availability, temperature and pH (Li et al., 2007; Vymazal, 2007; Hang et al., 2016). This is also supported by $\mathrm{N}$ balance results, which showed that $46.1 \%$ and $67.7 \%$ of supplied $\mathrm{N}$ in the APL and APH systems, respectively, were not recovered at the end of the experiment. Generally, denitrification is a significant pathway in AP systems contributing to $\mathrm{N}$ loss from $25 \%$ to $60 \%$ (Hu et al., 2015; Zou et al., 2016c), to which must be added the losses by ammonia volatilisation which is not negligible when aeration is provided and with a pH above 8.0 (Wongkiew et al., 2017b), as in the conditions of the present study. Considering that in AP systems the $\mathrm{N}$ can be converted into resources as long as the $\mathrm{N}$ is not transformed into high microbial biomass or nitrogen gas via denitrification (Wongkiew et $a l ., 2017 b$ ), our results suggest that initial fish stocking density is a key aspect that have a relevant and prolonged effect on AP system performance. Indeed, as reported in Maucieri et al. (2018b), at the end of the experiment APL treatment reach the same fish density of which observed in APH one at the beginning of the trial but oxygen concentration and $\mathrm{NO}_{3}{ }^{-}$availability were not negatively influenced. Plants $\mathrm{N}$ uptake is the main pathway of fish residual $\mathrm{N}$ recycling in AP and so an efficient system should show high crops yield and low amount of $\mathrm{N}$ loss in atmosphere (Wongkiew et al., 2017b). In our study the higher fish stocking density decreased the plants $\mathrm{N}$ uptake as a consequence of low $\mathrm{NO}_{3}{ }^{-}$availability, which likely occurred because of the low DO and the relatively high $\mathrm{pH}$ that also increased the $\mathrm{N}$ loss, thus reducing the system efficiency.

\section{Conclusions}

$\mathrm{N}$ balance showed that initial fish stocking density has a relevant and prolonged effect on AP system production performance with lower NUE and higher $\mathrm{N}$ loss through gas emissions with initial fish stocking density of $4.6 \mathrm{~kg} \mathrm{~m}^{-3}$ respect to $2.5 \mathrm{~kg} \mathrm{~m}^{-3}$. Therefore, our findings suggest that in a low-tech AP system a low initial fish density should be adopted at the system start up to maximise production and reduce $\mathrm{N}$ losses. Daily water evapotranspiration of proposed AP system gave typical performance of AP systems and was comparable with horticulture typical conditions showing that AP technology have higher water use efficiency than aquaculture and hydroponic section considered alone. Further researches are needed to confirm our results and to evaluate strategies to improve both nitrogen recovery in fish and vegetables and reduce $\mathrm{N}$ loss trough gas emissions.

\section{Highlights}

- The higher initial fish density had higher $\mathrm{N}$ input, but resulted in a lower $\mathrm{N}$ recovered in fish and vegetable biomass, and much higher $\mathrm{N}$ loss as gas emissions.

- The lower initial fish density combined a lower $\mathrm{N}$ input to a higher recovery in fish and vegetable biomass, and a lower $\mathrm{N}$ loss as gas emissions.

- The lower initial fish density allowed to maximise both production and environmental preservation. 


\section{References}

Akratos CS, Tsihrintzis VA, 2007. Effect of temperature, HRT, vegetation and porous media on removal efficiency of pilot-scale horizontal subsurface flow constructed wetlands. Ecol. Eng. 29:173-91.

Al-Rawahy MS, Al-Rawahy SA, Al-Mulla YA, Nadaf SK, 2019. Influence of nutrient solution temperature on its oxygen level and growth, yield and quality of hydroponic cucumber. J. Agr. Sci. 11:75-92.

Chen S, Ling J, Blancheton JP, 2006. Nitrification kinetics of biofilm as affected by water quality factors. Aquacult. Eng. 34:179-97.

Crab R, Avnimelech Y, Defoirdt T, Bossier P, Verstraete W, 2007. Nitrogen removal techniques in aquaculture for a sustainable production. Aquaculture 270:1-14.

Ehret DL, Edwards D, Helmer T, Lin W, Jones G, Dorais M, Papadopoulos AP. 2010. Effects of oxygen-enriched nutrient solution on greenhouse cucumber and pepper production. Sci. Hortic. 125:602-7.

Endut A, Jusoh A, Ali N, Nik WW, Hassan A, 2010. A study on the optimal hydraulic loading rate and plant ratios in recirculation aquaponic system. Bioresour. Technol. 101:1511-7.

Endut A, Jusoh A, Ali NA, 2014. Nitrogen budget and effluent nitrogen components in aquaponics recirculation system. Desalin. Water Treat. 52:744-52.

Fang Y, Hu Z, Zou Y, Fan J, Wang Q, Zhu Z, 2017. Increasing economic and environmental benefits of media-based aquaponics through optimising aeration pattern. J. Clean. Prod. 162:1111-7.

Goddek S, Delaide B, Mankasingh U, Ragnarsdottir KV, Jijakli H, Thorarinsdottir R, 2015. Challenges of sustainable and commercial aquaponics. Sustainability 7:4199-4224.

Goddek S, Joyce A, Kotzen B, Burnell GM, 2019. Aquaponics Food Production Systems - Combined aquaculture and hydroponic production technologies for the future. Springer, Berlin, Germany.

Grant J, Simone M., Daggett T. 2019. Long-term studies of lobster abundance at a salmon aquaculture site, eastern Canada. Canad. J. Fish. Aquatic Sci. 76:1096-102.

Gross A, Boyd CE, Wood CW, 2000. Nitrogen transformations and balance in channel catfish ponds. Aquacult. Eng. 24:1-14.

Hang Q, Wang H, Chu Z, Ye B, Li C, Hou Z, 2016. Application of plant carbon source for denitrification by constructed wetland and bioreactor: review of recent development. Environ. Sci. Pollut. R. 23:8260-74.

Hargreaves JA, 1998. Nitrogen biogeochemistry of aquaculture ponds. Aquaculture 166:181-212.

Hu Z, Lee JW, Chandran K, Kim S, Brotto AC, Khanal SK, 2015. Effect of plant species on nitrogen recovery in aquaponics. Bioresour. Technol. 188:92-8.

Jaeger C, Foucard P, Tocqueville A, Nahon S, Aubin J, 2019. Mass balanced based LCA of a common carp-lettuce aquaponics system. Aquacult. Eng. 84:29-41.

Jaxion-Harm J, Ladich F, 2014. Effects of temperature change on cortisol release by common carp Cyprinus carpio. J. Fish Biol. 84:1221-7.

Kinyage JPH, Pedersen LF, 2016. Impact of temperature on ammonium and nitrite removal rates in RAS moving bed biofilters. Aquacult. Eng. 75:51-5.

Koehn JD, 2004. Carp (Cyprinus carpio) as a powerful invader in Australian waterways. Freshw. Biol. 49:882-94.

König B, Junge R, Bittsanszky A, Villarroel M, Komives T, 2016. On the sustainability of aquaponics. Ecocycles 2:26-32.

Lara LJ, Egea-Gilabert C, Niñirola D, Conesa E, Fernández JA, 2011. Effect of aeration of the nutrient solution on the growth and quality of purslane (Portulaca oleracea). J. Hortic. Sci. Biotechnol. 86:603-10.

Li B, Irvin S, Baker K, 2007. The variation of nitrifying bacterial population sizes in a sequencing batch reactor (SBR) treating low, mid, high concentrated synthetic wastewater. J. Environ. Eng. Sci. 6:651-63.

Maucieri C, Nicoletto C, Junge R, Schmautz Z, Sambo P, Borin M,
2018.Hydroponic systems and water management in aquaponics: a review. Ital. J. Agron. 13:1-11.

Maucieri C, Nicoletto C, Zanin G, Birolo M, Trocino A, Sambo P, Borin M, Xiccato G, 2019.Effect of stocking density of fish on water quality and growth performance of European Carp and leafy vegetables in a low-tech aquaponic system. PLoS One 14:e0217561.

Maucieri C, Nicoletto C, Zanin G, Xiccato G, Borin M, Sambo P, 2020. Composition and quality traits of vegetables grown in a low-tech aquaponic system at different fish stocking densities. J. Sci. Food Agricult. [In press].

Muralidhar M, Saraswathy R, Dayal JS, Vass KK, 2017. Nitrogen assessment and management in brackish-water aquaculture of India. In: Abrol YP, Adhya TK, Aneja VP, Raghuram N, Pathak H, Kulshrestha U, Sharma C, Singh B (Eds.), The Indian Nitrogen Assessment. Elsevier, Amsterdam, The Netherlands, pp 287-303.

Paudel SR, 2020. Nitrogen transformation in engineered aquaponics with water celery (Oenanthe javanica) and koi carp (Cyprinus carpio): effects of plant to fish biomass ratio. Aquaculture 520:734971.

Schwarz FJ, Kirchgessner M, Deuringer U, 1998. Studies on the methionine requirement of carp (Cyprinus carpio L.). Aquaculture 161:121-9.

Skibniewska KA, Zakrzewski J, Kłobukowski J, Białowiąs H, Mickowska B, Guziur J, Walczak Z, Szarek J, 2013. Nutritional value of the protein of consumer carp. Czech. J. Food Sci. 31:313-7.

Somerville C, Cohen M, Pantanella E, Stankus A, Lovatelli A, 2014.Small-scale aquaponic food production: integrated fish and plant farming. FAO Fisheries and Aquaculture Technical Paper, Rome, Fasc. 589.

Trejo-Téllez LI, Gómez-Merino FC, 2012. Nutrient solutions for hydroponic systems. Asao T. (Ed.), Hydroponics - a Standard Methodology for Plant Biological Researches. InTech, Rijeka, Croatia, p. 244.

Tyson RV, Simonne EH, White JM, Lamb EM, 2004. Reconciling water quality parameters impacting nitrification in aquaponics: the $\mathrm{pH}$ levels. In. Proc. Fla. State Hort. Soc. 117:79-83.

Tyson RV, Treadwell DD, Simonne EH, 2011. Opportunities and challenges to sustainability in aquaponic systems. Hort. Technol. 21:6-13.

Vymazal J, 2007. Removal of nutrients in various types of constructed wetlands. Sci. Total Environ. 380:48-65.

Wongkiew S, Hu Z, Chandran K, Lee JW, Khanal SK, 2017b. Nitrogen transformations in aquaponic systems: a review. Aquacult. Eng. 76:9-19.

Wongkiew S, Popp BN, Kim HJ, Khanal SK, 2017a. Fate of nitrogen in floating-raft aquaponic systems using natural abundance nitrogen isotopic compositions. Int. Biodeter. Biodegr. 125:24-32.

Xu JH, He SB, Wu SQ, Huang JC, Zhou WL, Chen XC, 2016. Effects of HRT and water temperature on nitrogen removal in autotrophic gravel filter. Chemosphere 147:203-9.

Yamamoto T, Takaki K, Koyama T, Furukawa K, 2008. Long-term stability of partial nitritation of swine wastewater digester liquor and its subsequent treatment by Anammox. Bioresour. Technol. 99:6419-25.

Yogev U, Barnes A, Gross A, 2016. Nutrients and energy balance analysis for a conceptual model of a three loops off grid, aquaponics. Water 8:589.

Zou Y, Hu Z, Zhang J, Guimbaud C, Wang Q, Fang Y, 2016b. Effect of seasonal variation on nitrogen transformations in aquaponics of northern China. Ecol. Eng. 94:30-6.

Zou Y, Hu Z, Zhang J, Xie H, Guimbaud C, Fang Y, 2016c. Effects of pH on nitrogen transformations in media-based aquaponics. Bioresour. Technol. 210:81-7.

Zou Y, Hu Z, Zhang J, Xie H, Liang S, Wang J, Yan R, 2016a. Attempts to improve nitrogen utilisation efficiency of aquaponics through nitrifies addition and filler gradation. Environ. Sci. Pollut. R. 23:6671-9. 